\title{
Tolerable Risk for Hydrogen Sulfide in Sewage Treatment Plant- STP
}

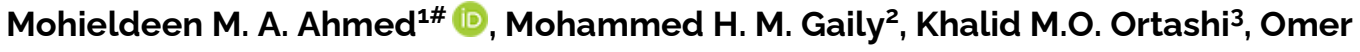 \\ M.A. Al Ghabshawi ${ }^{4}$, Nagwa F. Bashir ${ }^{5}$, Osman M. M. Ali ${ }^{6}$ \\ 1,2,6 University of Khartoum, Institute of Environmental Studies, Ministry of Higher Education and \\ Scientific Research, Khartoum, Sudan. \\ ${ }^{3}$ University of Khartoum, Faculty of Engineering, Dept. of Chemical Engineering, Ministry of \\ Higher Education and Scientific Research, Khartoum, Sudan. \\ ${ }^{4}$ Sudan University of Science and Technology, Faculty of Petroleum Engineering, Ministry of \\ Higher Education and Scientific Research, Khartoum, Sudan. \\ ${ }^{5} \mathrm{Al}-\mathrm{Neelain}$ University, Faculty of Sciences and Technology, Dept. of Chemical Engineering, \\ Ministry of Higher Education and Scientific Research, Khartoum, Sudan.
}

\#corresponding author

Type of Work: Peer Reviewed.

DOI: 10.21013/jas.v16.n4.p3

DOI URL: https://dx.doi.org/10.21013/jas.v16.n4.p3

\section{How to cite this paper:}

Ahmed, Mohieldeen M. A. et al. (2021). Tolerable Risk for Hydrogen Sulfide in Sewage Treatment Plant- STP. IRA-International Journal of Applied Sciences (ISSN 2455-4499), 16(4), 74-83. DOI: https://dx.doi.org/10.21013/jas.v16.n4.p3

(C) IRA Academico Research.

(cc) BY-Nc This work is licensed under a Creative Commons Attribution-NonCommercial 4.0 International License subject to a proper citation to the publication source of the work.

Disclaimer: The scholarly papers as reviewed and published by IRA Academico Research are the views and opinions of their respective authors and are not the views or opinions of IRA Academico Research. IRA Academico Research disclaims any harm or loss caused due to the published content to any party.

IRA Academico Research is an institutional publisher member of Publishers International Linking Association Inc. (PILA-CrossRef), USA. IRA Academico Research is an institutional signatory to the Budapest Open Access Initiative, Hungary advocating the open access of scientific and scholarly knowledge. IRA Academico Research is also a registered content provider under Open Access Initiative Protocol for Metadata Harvesting (OAI-PMH).

This paper is peer-reviewed under IRA Academico Research's Peer Review Program.

Mohieldeen M. A. Ahmed (D)/0000-0001-7898-2583 


\begin{abstract}
Hydrogen sulphide is a toxic gas, it can cause a range of physiological responses from simple annoyance to permanent injury and death. There are a number of approaches to deal with the impacts of toxic gases. This study focused on minimizing the hazard exposure for hydrogen sulfide in the different operational zones for activated sludge process in sewage waterplant. Research tools/ approaches conducted were interviews, toxic gas testers, analysis report interpretation \& quantitative risk assessment method. The study was conducted on Arabian Peninsula during the period (September 2019- September 2021). The (13) operational locations tested for toxic gas concentrations were inlet chamber, outlet channel, coarse /fine screens, primary sedimentation tank, activated sludge tanks, secondary sedimentation tanks, gas desulfurization unit, disc filters, chlorine dosing unit, sludge dewatering, sludge silos and digester tanks. The study found that the highest concentration for $\mathrm{H}_{2} \mathrm{~S}$ in the inlet chamber/ outlet channel. The severity hazards in the sewage treatment plant using activated sludge process are the asphyxiation by $\mathrm{H}_{2} \mathrm{~S}$ was extremely high can cause harm to public health, followed by the radiation hazard followed by electrical hazard, then (working at height, mechanical, traffic, health, chemical, physical, ergonomic, environmental, microbial and natural). The frequency of hazards occurrence is asphyxiation by $\mathrm{H}_{2} \mathrm{~S}$ was extremely high followed by the radiation hazard and health hazard including the infection with Covid 19 virus followed by mechanical hazard then (electrical, traffic, ergonomic, natural, chemical, physical and natural). Control measures were recommended to minimize the risk of asphyxiation by $\mathrm{H}_{2} \mathrm{~S}$ in the working environment at the STP.
\end{abstract}

Keywords: Hydrogen sulfide, risk assessment, sewage treatment plant- STP

\title{
Introduction
}

Wastewater needs our attention because water is a basic necessity for humans to carry out their lives. Most of the causes of the disease are from water, according to WHO data in 2002 alone $80 \%$ of the disease was caused by poor water quality due to microbiological contamination [1]. The municipal sewage pipe network collects and delivers waste water from the city to STP. Since the waste water treatment plants are situated out the inhabited districts, wastewater should be transported there through the network of pumping stations[2]

Reuse of wastewater is becoming increasingly unavoidable as a result of the dynamic climate change due to the growing scarcity of water resources. On the contrary, greenhouse gases associated with nitrification/denitrification processes occur as an intermediate product during wastewater treatment. They are emitted into the atmosphere [3] The pre-treatment stage consists of an inlet pumping station, coarse screen, fine screen, grit and grease chambers and primary sedimentation. In the first step, the wastewater is lifted to the static pressure head from which the water can flow through the plant by gravity. Afterwards, the wastewater is screened by the coarse screen and fine screens to remove the floating and coarse substances from the wastewater to protect the downstream facilities against damage and the screenings are dewatered and discharged into disposal skips. Afterwards, the mineral fraction of sand and grit are separated to avoid any uncontrolled sedimentation somewhere in channels, tanks or pipelines. The grit is dewatered and collected at disposal skips. The aeration floats the greases fraction, is removed and pumped to the anaerobic sludge stabilization. The pre-treated wastewater flows from the grit and grease removal to the primary sedimentation. The fine settleable suspended solids are separated to relieve the biological treatment, to reduce the volume of aeration tanks, oxygen demand and to lower thereby the operation costs. The primary sludge is transferred to the anaerobic sludge stabilization. The biological treatment is the second section of the treatment process. The pre-treated wastewater is mixed with the biomass of the return activated sludge before entering the biological stage. In the different zone with and without dissolved oxygen, various biological treatment process is taking place to purify the wastewater. The required oxygen is inserted by surface aerators. The internal recycle pumps transfer the intermediate products like nitrate from the end to the beginning of the process stage for nitrogen removal purposes. During the biodegradable process, biomass is produced, which is separated from the treated wastewater at the secondary sedimentation tanks. Most of the collected sludge is returned to provide sufficient biomass for the biological removal processes. A small part of the biomass is taken from the system as surplus sludge and is further treated at the anaerobic sludge treatment. The tertiary treatment is the last step of the waterline treatment process. The treated water from the secondary sedimentation flows to the disc filtration to remove the remaining solids and to lower the remaining effluent pollution. The final step is the disinfection of the water before it is discharged into the effluent channel of all the treatment plants. The sludge line consists of surplus sludge thickening, anaerobic sludge stabilization, dewatering, storage and disposal of digested sludge. The biogas is purified, stored and used for energy production and for heating the digesters. The primary sludge is pumped directly 
into the digester and the surplus sludge is thickened before. The target is the biogas and power production, sludge stabilization and the reduction of sludge volume. In the digester the sludge is agitated and a part is cycled through heat exchange to achieve a constant temperature. The anaerobic organisms are transferring the incoming substrates into biogas, consisting of methane and carbon dioxide. The biogas is extracted, purified by removing Sulphur, moisture and dust and stored to equalize the biogas flow. The biogas pressure is increased by a booster station and is consumed as fuel at the co-generation for power production. The by-product heat is used for heating the digester to improve the degradation process. The digested sludge is dewatered and intermediately stored in silos before it is disposed of. Waste air from preliminary treatment and sludge treatment is extracted and sent to the odor treatment.

The tertiary treatment adds a third, more advanced and rigorous level of treatment. Primary and secondary treatment typically get wastewater only clean enough to discharge safely into the environment. Tertiary treatment can achieve levels of water purification that make the water safe for reuse in water-intensive processes. Despite EU efforts toward its minimization, landfilling is still the widest implemented method for the final disposal of municipal sludge[4].

\section{Literature review}

For many years, wastewater treatment plants have been regarded as dangerous work environments. Treatment plant workers experience health problems, accidents and near-misses resulting from exposure to a wide range of hazards related to plant design and processes[5].

Hydrogen sulfide gas is also known as "sewer gas" because it is often produced by the breakdown of waste material. At low levels, hydrogen sulfide gas has a strong odor similar to rotten eggs. However, at higher levels, can become overwhelmed by the gas and cannot smell it and could be fatal. Hydrogen sulfide is colorless, flammable gas under normal conditions. It is commonly known as hydro-sulfuric acid, stinks damp and sewer gas. Exposure to lower concentrations of $\mathrm{H}_{2} \mathrm{~S}$ can cause eye irritation, a sore throat and cough, shortness of breath and fluid in the lungs. These symptoms usually go away in a few weeks after exposure ends. Long-term, low-level exposure may result in fatigue, loss of appetite, headaches, irritability, poor memory and dizziness. Breathing very high levels of hydrogen sulfide can cause death within just a few breaths. There could be a loss of consciousness after one or more breaths[6].

Hazards of hydrogen sulfide; toxic, invisible, heavier than air, flammable and explosive, corrosive and reactive Concentration and Effects:

$0.10 \mathrm{ppm}$ - Foul, rotten egg smell noticeable.

10 ppm - TLV-TWA; eye irritation; use SCBA.

$15 \mathrm{ppm}$ - Short-term exposure limit (STEL) for 15 minutes.

$50 \mathrm{ppm}$ - Maximum peak exposure (MPE).

$100 \mathrm{ppm}$ - IDLH; severe eye irritation, coughing, loss of sense of smell in 1 to 5 minutes.

250 ppm - Pulmonary edema; gastrointestinal disturbance.

$500 \mathrm{ppm}$ - Dizziness; loss of consciousness within 30 minutes.

$1,000 \mathrm{ppm}$ - Death within minutes.

Utilities: administration building with central control room, Central electrical power distribution station, MCC and substation, laboratory, workshop, warehouse, accommodation building, Service water pumping station and network, Potable water storage, pumping station and network, guard house and landscaping) 


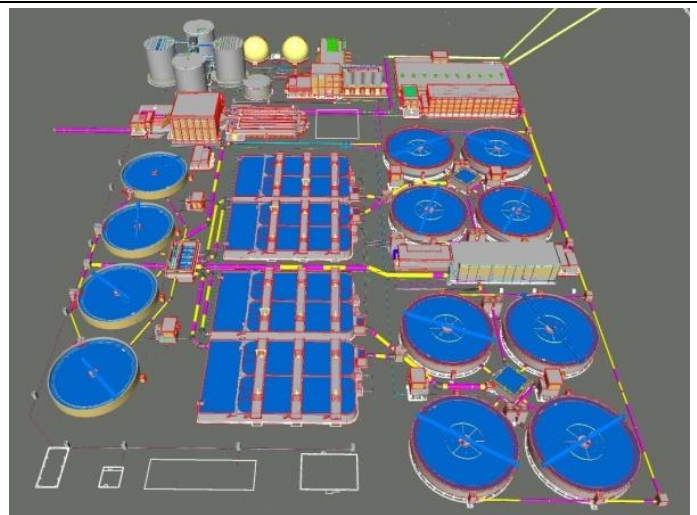

Picture (1) for STP layout

In confined spaces and other covered areas, the potential exists for atmospheric concentrations to develop that become immediately dangerous to life and health (IDLH). An IDLH condition can be defined as an atmospheric concentration of any toxic, corrosive, or asphyxiant substance (simple or chemical) that "poses an immediate threat to life or would cause irreversible or delayed adverse health effects or would interfere with an individual's ability to escape from a dangerous atmosphere" (OSHA, 2008C). Following are the main IDLH concerns when handling the production of biogas (Center for Disease Control and Prevention, 1995).

- Oxygen deficiency - less than 19.5 percent by volume air

- Hydrogen sulfide - more than $100 \mathrm{ppm}$

- Ammonia - more than 300 ppm

- Carbon dioxide - more than 40,000 ppm

Three types of invisible dangers can be found in sewer manholes or "confined space" within the system. They are; explosive gases, lack of oxygen and hydrogen sulfide gas[7]

Odor control system is an air treatment system able to reduce the main pollutant (mainly $\mathrm{H}_{2} \mathrm{~S}$, mercaptans) contained into an exhaust air stream coming from STP. During the long retention time of the wastewater in the sewer by a high temperature, some of the degradation processes will have started and gases have been produced. At the first stages of the treatment plant until the wastewater is enriched with oxygen and at the surplus sludge thickening, the sludge storing and dewatering gases can be released, which are summarized as waste air. These areas are connected to the odor treatment network of the odor treatment.

The odor control system is designed to remove at least $99.5 \%$ of the waste gases from the area within a temperature range of 5 to $60^{\circ} \mathrm{C}$ and a humidity range of 10 to $100 \%$. The main pollution components of the waste air are commonly found in sewage waste air: Hydrogen sulphide, Methyl mercaptans, Methylamine, Ammonia, Nitrogen, Sulphur compounds and volatile organic compounds.

In case of the removal of ammonia and other nitrogen compounds are required, a dilute (10\%) sulphuric acid solution $\left(\mathrm{H}_{2} \mathrm{SO}_{4}\right)$ is used in the first stage to reduce the $\mathrm{pH}$ down to 2 . The ammonia reacts with the sulphuric acid to form ammonium sulphate, a soluble, non-volatile salt, which is removed from the scrubber effluent through the overflow. The microorganisms consume the odorous contaminants for covering their energy demand and cleaning thereby the waste air.

Risk is a measurement to analyze and evaluate the hazard. The measurement is made by identification on how severe and when likely of the hazard is. In other words, the risk assessment is an in-depth look to specify situations, processes and other harmful activities or hazards at the workplace [9]

Aim of the study: The purpose of this paper is to study hazard identification as a proactive process to eliminate or minimize/reduce the risk of injury/illness to workers and damage to property, equipment and the environment for the major chemicals, biogas and $\mathrm{H}_{2} \mathrm{~S}$ associated with an activated sludge at the sewage treatment plant. 
IRA-International Journal of Applied Sciences

Materials and methods

i. Case Study: A Sewage Treatment Plant (STP) with a capacity of $100,000 \mathrm{~m}^{3} / \mathrm{d}$. was selected for further investigations. The plant consists of primary and secondary treatment processes with sludge treatment and disposal facilities. The study was conducted on Arabian Peninsula during the period (September 2019 - September 2021).

ii. Hazard identification (HIRA) is a process of identifying and describing hazards by describing their probability, frequency, and severity and assessing adverse consequences, including potential loss and injury.[8].The industry needs to identify hazards and assess associated risks for tolerance on an ongoing basis using risk assessment standards and guidelines. Risk assessment is a method of systematically Identifying and analyzing hazards associated with an activity and establishing the level of risk for each hazard Hazards cannot be eliminated, and therefore it is necessary to determine and estimate the extent to which an accidental risk can be prevented quantitatively or qualitatively of the hazard mechanism. [8].

iii. Semi-structured interviews are used as exploratory methods to gather descriptive data on a defined subject under investigation, the interviews, aiming to characterize what they identify as risks. Using a handheld multi-gas detector capable of detecting oxygen, carbon monoxide, hydrogen sulfide, and lower explosive limits (LEL) levels for testing the atmosphere within a confined space according to OSHA general industry standard 1910.146 (1998)

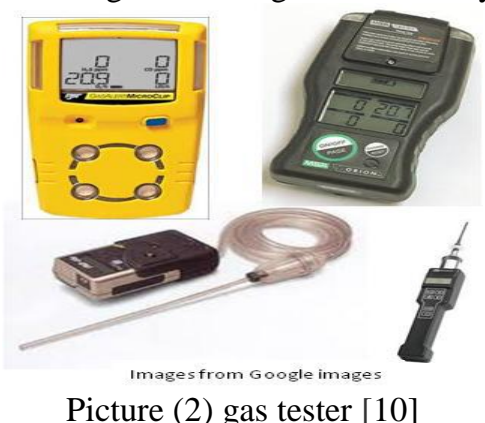

\section{Results}

Picture (2) gas tester [10]

Referring to figure (1), $\mathrm{H}_{2} \mathrm{~S}$ tested by the calibrated gas tester at sewage treatment plant - STP as indicted in for H2S trend analysis including (13) different locations; inlet chamber, outlet channel, coarse /fine screens, primary sedimentation tank, activated sludge tanks, secondary sedimentation tanks, gas desulfurization unit, disc filters, chlorine dosing unit, sludge dewatering, sludge silos and digester tanks. The study found that the highest concentration for $\mathrm{H}_{2} \mathrm{~S} / \mathrm{ppm}$ is detected at the inlet chamber/ outlet channel, where other locations showed approximately equal readings for $\mathrm{H}_{2} \mathrm{~S}$.

Referring to figure (2), the number of safety observations reports (SOR) extracted from the SOR register which represents the frequency of incidents occurrence versus hazard category which is indicated in the blue column, the number of nonconformity reports (NCR) extracted from (NCR) register for the sewage treatment plant during the period (September 2019- September 2021) represents the severity of incidents versus the hazard category indicated in the red column.

The severity hazards in the sewage treatment plant using activated sludge process are the asphyxiation by $\mathrm{H}_{2} \mathrm{~S}$ was extremely high can cause harm to public health, followed by the radiation hazard followed by electrical hazard, then (working at height, mechanical, traffic, health, chemical, physical, ergonomic, environmental, microbial and natural). The frequency of hazards occurrence is asphyxiation by $\mathrm{H} 2 \mathrm{~S}$ was extremely high followed by the radiation hazard and health hazard including the infection with Covid 19 virus followed by mechanical hazard then (electrical, traffic, ergonomic, natural, chemical, physical and natural). Control measures were recommended to minimize the risk in the working environment at the STP.

\section{Conclusion}

Potential occupational hazards in the water treatment industry are exposed chemicals to workers, the potential danger of leaking hydrogen sulfide gas can also greatly affect the safety and health of the STP environment. Control measures undertaken to avoid potential hazards are to apply the use of personal protective equipment including SCABA but better management in accordance with hazard control and health programs such as issuing work permits, emergency response training is required, very useful in overcoming potential hazards that have been 
determined. Site operators and designated staff should be trained to supervise the response to spill incidents and, if necessary, to liaise with emergency response personnel such as the civil defence authority.

- Measuring devices and equipment, like flame arrestors, are installed to control, the biogas system against the uncontrolled spread of fire and explosion

- Equipment that may produce sparks may not be used. Safe performance of work, with special attention to cleaning, maintenance and troubleshooting.

\section{Recommendations for Controlling the Hazards of Asphyxiation by $\mathrm{H}_{2} \mathrm{~S}$ :}

Since most of the STP technology is activated automatically using SCADA, it is essential to have well-secured facilities where machinery and equipment are used, and the operator should pay close attention to the movement in the location around these facilities, special engineering and administrative controls should be applied;

- Engineering controls; safe and effective design, construction, operation and maintenance, transportation and storage equipment. Ventilation (using exhaust fans, air pumps), flaring systems (safely burn remaining gas).

- Administrative controls; assigning workers to work in areas with no potential for $\mathrm{H}_{2} \mathrm{~S}$ exposure or limiting their work time in certain environments, substituting with less hazardous materials. Implementing procedures to safely handle substances. Use Supplied Air Breathing Apparatus for rescue in confined spaces

- Emergency response plans; stop work and warn others, use the beacon to identify leak location, check wind direction, evacuate upwind/crosswind and move to higher ground.

\section{References}

[1]. Fauziah Raya Shinta, Nieke Karnaningroem and Mas Agus Mardyanto (2019): Risk Management of Wastewater Treatment in the Wastewater Treatment Plant of PT. X, IPTEK Journal of Proceedings Series No. (5) (2019), ISSN (2354-6026), Indonesia

[2]. Jelena Sulojeva, Aleksejs Percovs, Jel̦ena Maļukova, Valentina Urbane, Riga Technical (2011): Occupational Safety Management Aspects on Municipal Waste Water Treatment Plant, Scientific Journal of Riga Technical University Safety of Technogenic Environment

[3]. Irena Tušer and Alena Oulehlová (2021): Risk Assessment and Sustainability of Wastewater Treatment Plant Operation, https://doi.org/10.3390/ su13095120, Switzerland.

[4]. S. Sözen, E. Ubay Cokgor, G. Insel, D. Okutman T, H. Dulkadiroglu, C. Karaca, A. Filibeli, S. Meric, D. Orhona (2014): http://dx.doi.org/10.1016/j.wasman.2014.05.0240956-053X/ 2014 Elsevier Ltd

[5]. Amirhossein Malakahmad, Alan Giffin Downe, Siti Dhamina Muhamad Fadzil (2014): Application of Occupational Health and Safety Management System at Sewage Treatment Plants, https://www.researchgate.net/publication/261499796, Malaysia

[6]. Petr Trávníček, Luboš Kotek, Tomáš Koutný, Tomáš Vítěz (2019): Quantitative Risk Assessment of Biogas Plant - Determination of Assumptions and Estimation of Selected Top Event, Periodica Polytechnica Chemical Engineering, 63(3), pp.397-405, https://doi.org/10.3311/PPch.13048

[7]. Ho Tong Tron, Nguyen Hien Than (2021): Hazard Identification and Risk Assessment in Wastewater Treatment Plant of Di An City, Thu Dau Mot University Journal of Science - Volume 3, Thu Dau Mot University, https://doi.org/10.37550/tdmu.EJS/2021.01.154

[8]. Alex M, Dr K. Muthukumar (2021): Hazard Identification and Risk Assessment in Sewage Treatment Plant, International Research Journal of Engineering and Technology (IRJET), Volume: 08 Issue: 04 www.irjet.net, India

[9]. Fajrul Falakh, Onny Setiani (2018): Hazard Identification and Risk Assessment in Water Treatment Plant considering Environmental Health and Safety Practice; published by EDP Sciences, Indonesia.

[10]. United States Environmental Protection Agency (2011): Safety Practices for On-Farm Anaerobic Digestion Systems office of air and radiation, mail code 6207J, www.epa.gov 


\section{TABLES \& FIGURES}

Table (1): Raw wastewater quality

\begin{tabular}{l|l|c|c|c} 
Items & Units & $\mathbf{5 \%}$ & Average & $\mathbf{9 5 \%} * *$ \\
\hline $\mathrm{pH}$ & - & 6.9 & 7.5 & 8.6 \\
\hline $\begin{array}{l}\text { Temperatu } \\
\text { re }\end{array}$ & ${ }^{\circ} \mathrm{C}$ & 20 & 29 & 35 \\
\hline Alkalinity & $\begin{array}{l}\mathrm{mgCaCO} \\
3 / 1\end{array}$ & 140 & 160 & 200 \\
\hline TDS & $\mathrm{mg} / \mathrm{l}$ & 1,100 & 1,330 & 1,800 \\
\hline TSS & $\mathrm{mg} / \mathrm{l}$ & 250 & 360 & 650 \\
\hline $\mathrm{COD}$ & $\mathrm{mg} / \mathrm{l}$ & 400 & 550 & 850 \\
\hline BOD & $\mathrm{mg} / \mathrm{l}$ & 240 & 330 & 500 \\
\hline $\mathrm{NH}_{4}-\mathrm{N}$ & $\mathrm{mg} / \mathrm{l}$ & 15 & 27 & 40 \\
\hline TKN & $\mathrm{mg} / \mathrm{l}$ & 38 & 48 & 60 \\
\hline TP & $\mathrm{mg} / \mathrm{l}$ & 6.0 & 7.2 & 9.0 \\
\hline & & & & \\
\hline
\end{tabular}

* $5 \%$ of daily average figures of a period of a least 80 days are expected below the given figures ** $95 \%$ of daily average figures of a period of a least 80 days are expected below the given figures

Table (2): Treated Water effluent quality

\begin{tabular}{l|l|c} 
Items & Units & Value \\
\hline & & \\
\hline $\mathrm{pH}$ & - & $6.0-8.4$ \\
\hline $\mathrm{TDS}$ & $\mathrm{mg} / \mathrm{l}$ & $<2,500$ \\
\hline Turbidity & $\mathrm{NTU}$ & $<10$ \\
\hline & & \\
\hline $\mathrm{TSS}$ & $\mathrm{mg} / 1$ & $<10$ \\
\hline $\mathrm{BOD}_{5}$ & $\mathrm{mg} / 1$ & $<10$ \\
\hline $\mathrm{NO}_{3}-\mathrm{N}$ & $\mathrm{mg} / 1$ & $<10$ \\
\hline $\mathrm{NH}_{4}-\mathrm{N}$ & $\mathrm{mg} / 1$ & $<5$ \\
\hline $\mathrm{Cl}_{2 \text { free }}$ & $\mathrm{mg} / 1$ & $>0.5$ \\
\hline $\begin{array}{l}\text { Intestinal } \\
\text { Worms }\end{array}$ & & \\
(Helminth) & & - \\
Eggs & & \\
\hline Faecal Coliform & $1 / 100$ & $\mathrm{ml}$ \\
\hline
\end{tabular}

Table (3) Overview of physical details for flammables and combustibles at the STP 
IRA-International Journal of Applied Sciences

\begin{tabular}{|c|c|c|c|c|c|c|}
\hline $\begin{array}{c}\text { Relevant } \\
\text { substances }\end{array}$ & $\begin{array}{c}\text { Explosion } \\
\text { limit in } \\
\text { air }\end{array}$ & $\begin{array}{c}\text { Ignition } \\
\text { temperature }\end{array}$ & $\begin{array}{c}\quad \begin{array}{c}\text { Air } \\
\text { density } \\
=\text { Relative }\end{array}\end{array}$ & $\begin{array}{c}\text { Gas } \\
\text { density, } \\
013 \text { mbar } \\
\text { and } 15 \\
{ }^{\circ} \mathrm{C}\end{array}$ & Flashpoint & $\begin{array}{c}\text { Solubility } \\
\text { in water, } \\
013 \text { mbar } \\
\text { and } 2 \\
{ }^{\circ} \mathrm{C}\end{array}$ \\
\hline & [Vol.-\%] & {$\left[{ }^{\circ} \mathbf{C}\right]$} & {$[-]$} & {$\left[\mathrm{kg} / \mathrm{m}^{3}\right]$} & {$\left[{ }^{\circ} \mathbf{C}\right]$} & [vol/vol] \\
\hline $\begin{array}{l}\text { Biogas } \\
(68 \% \\
\mathrm{CH}_{4} \& 26 \\
\left.\% \mathrm{CO}_{2}\right)\end{array}$ & $6.3-19.7$ & $>595$ & 0.90 & 0.85 & & 0.054 \\
\hline Methane & $4.4-17.0$ & 540 & 0.55 & 0.68 & -188 & 0.054 \\
\hline $\begin{array}{l}\text { Methanol- } \\
\text { solution }\end{array}$ & $6-50$ & $>440$ & & & $9-54$ & \\
\hline $\begin{array}{l}\text { Ethanol- } \\
\text { solution } \\
(70 \%)\end{array}$ & $3.1-27.7$ & 363 & & & 16.6 & \\
\hline $\begin{array}{l}\text { LPG } \\
\text { (Propane) }\end{array}$ & $1.4-10.8$ & $>470$ & 1.55 & 1.898 & -104 & \\
\hline $\begin{array}{l}\text { Gasoline } \\
\text { (Petrol) }\end{array}$ & $0.6-8.0$ & 280 & $\begin{array}{l}3.2 \\
\text { (vapour) }\end{array}$ & $\begin{array}{l}0.72- \\
0.775 \\
\end{array}$ & -43 & 0.039 \\
\hline $\begin{array}{l}\text { Hydrogen } \\
\text { sulphide } \\
\mathrm{H}_{2} \mathrm{~S} \\
\end{array}$ & $4.3-46.0$ & 232 & 1.18 & 1.453 & -82.4 & 4.67 \\
\hline
\end{tabular}

\section{$\mathrm{H}_{2} \mathrm{~S}$ Trend Analysis in Sewage Treatment Plant -STP}

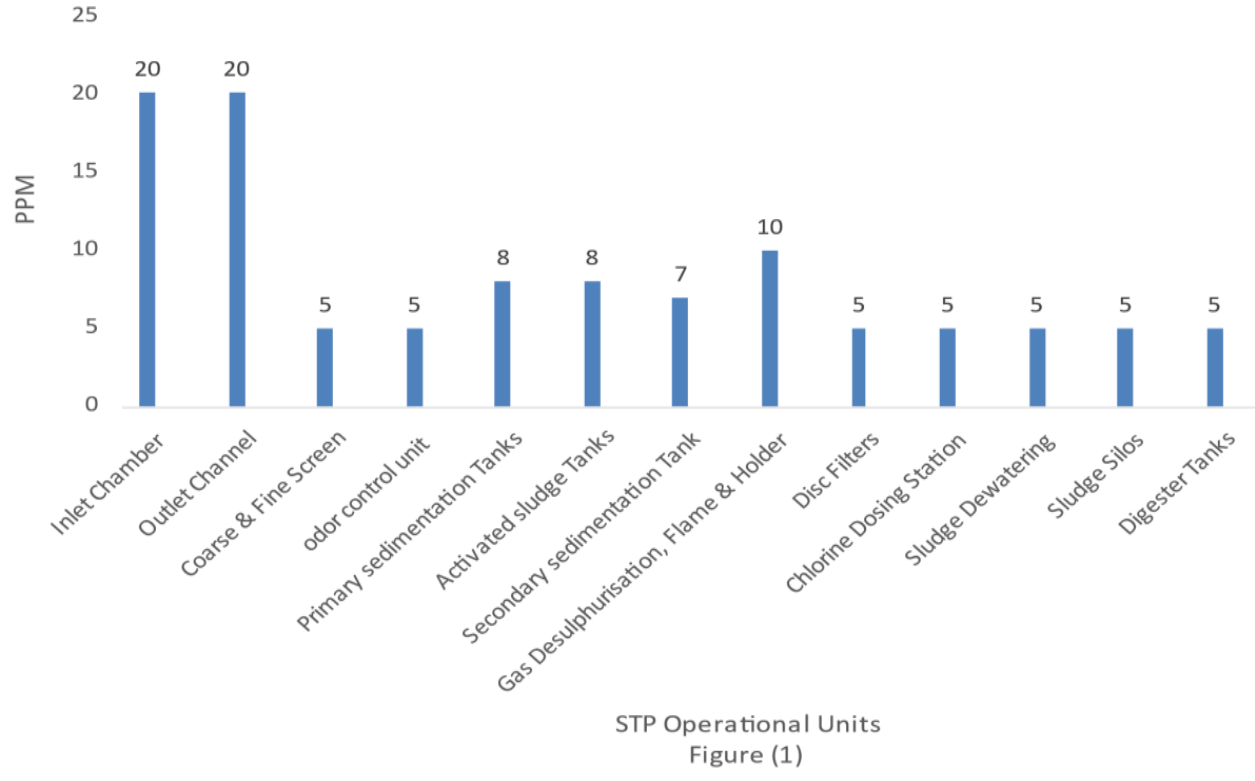


SOR / NCR - Trend Analysis (Sep. 2019 - Sep. 2021)

Safety Observation Reports (SOR ) /Non Conformance Reports (NCR) Analyzing Frequency and Severity Report in STP

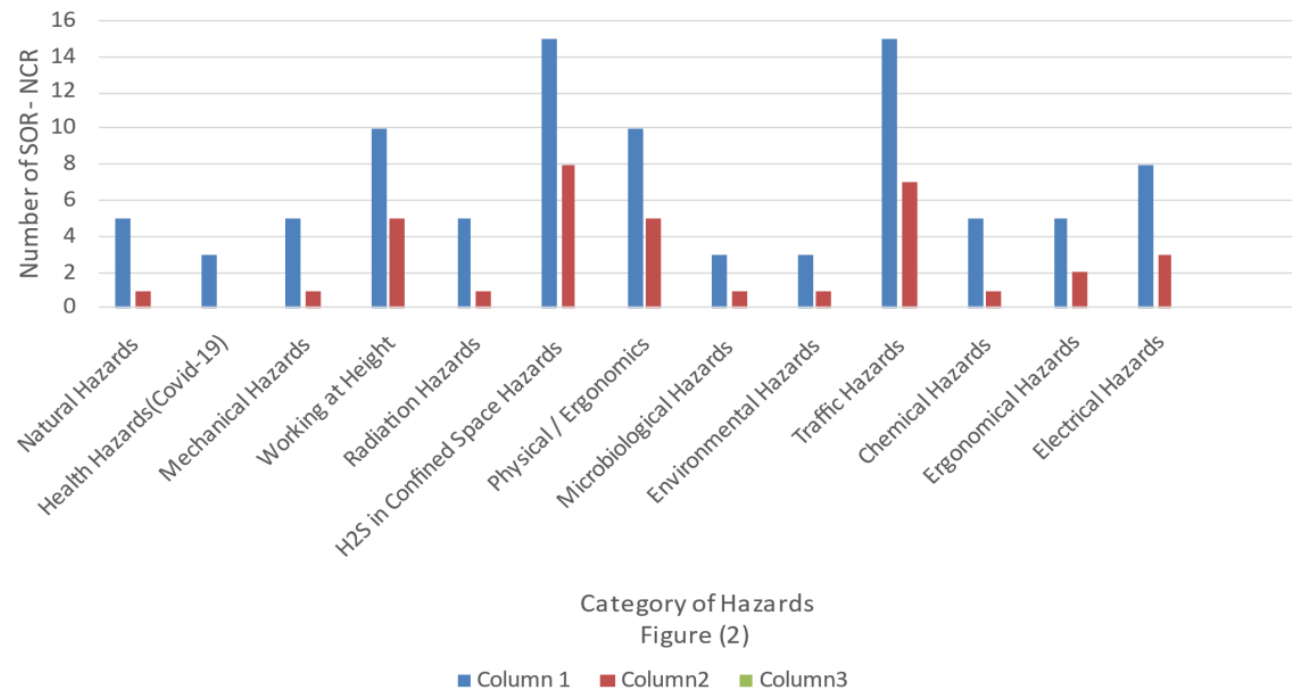

SOR / NCR - Trend Analysis From Sep 2019 to Sep 2021

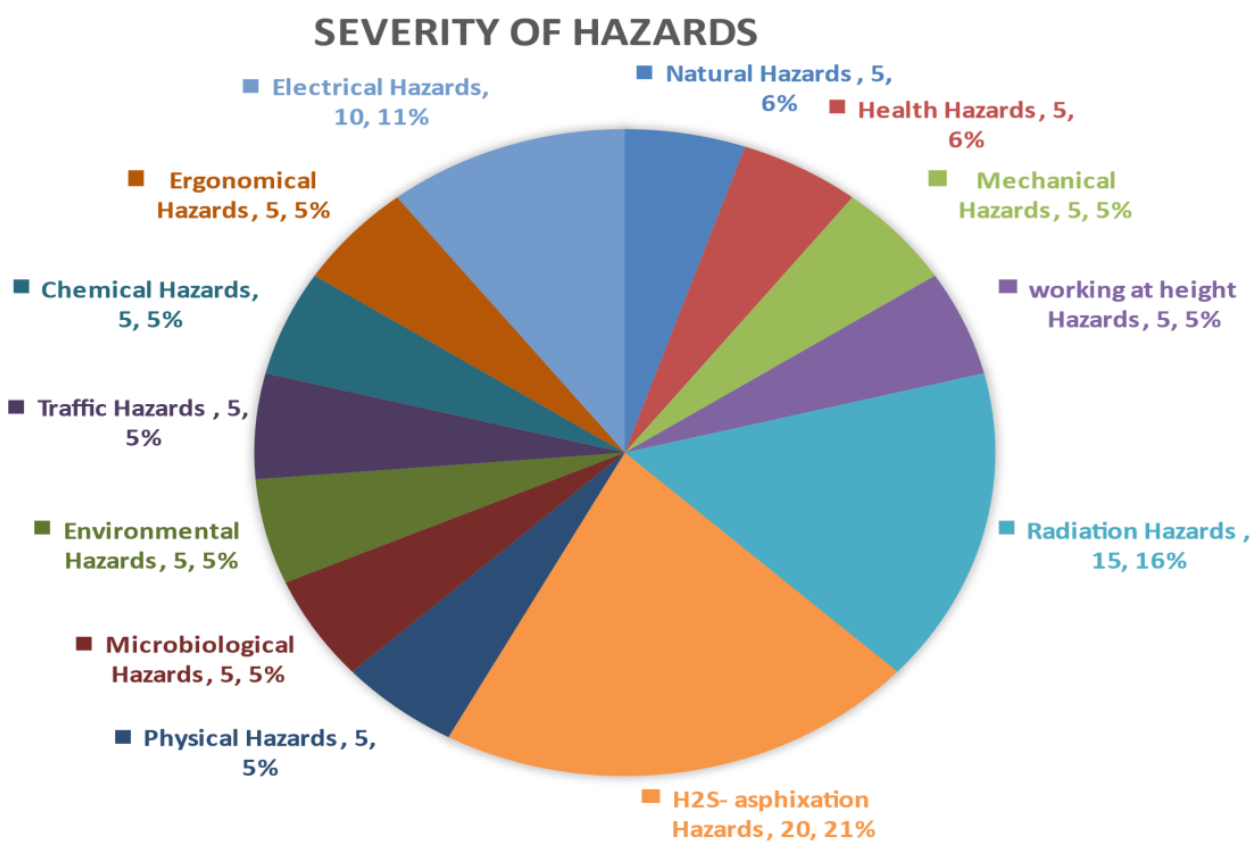

Figure (3) 
SOR / NCR - Trend Analysis From Sep 2019 to Sep 2021

\section{FREQUENCY OF HAZARDS}

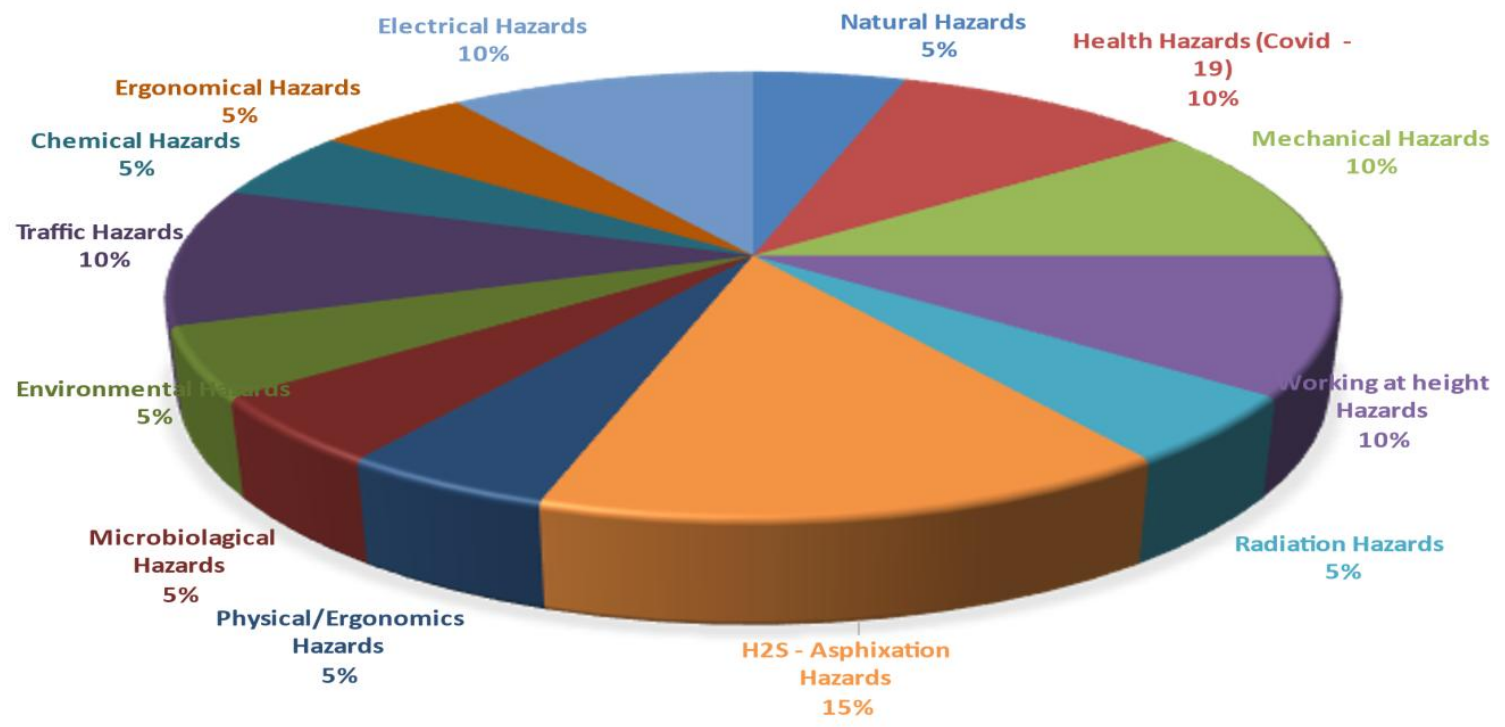

Figure (4) 